\title{
ECONOMIC INTEGRATION AND INVESTMENT OPPORTUNITIES: A STUDY ON ASEAN+3 COUNTRIES
}

\author{
MD. SAIFUR RAHMAN*, FARIHANA SHAHARI**
}

\begin{abstract}
This paper aims to investigate the investment opportunities in ASEAN+3 economies following the market liberalization in 1980s and 1990s. The estimation process is executed by using stock market indices and by employing Johansen Cointegration, VECM and Impulse response function. Member economies of ASEAN+3 are segmented based on income level in order to observe the market dominance of developed economy on that of developing economies. The dynamic findings indicate the followings: 1) the capital market liberalization improves the market transparency, thus to the favor of the foreign investment, 2) The diversification benefits of portfolio investment in APT regional financial markets squeezed, 3) both the higher and lower income economies have equal investment opportunities, and finally, 4) the financial markets of ASEAN+3 become excellent investment region. This study offers great policy implications for the regional policy makers and both foreign and local investors.
\end{abstract}

Keywords: financial market, investment opportunity, cointegration analysis, global Investors

JEL Classification: $F 1, F 3, G 1$

\section{INTRODUCTION}

Openness of ASEAN Plus three (APT) capital markets took effect since late 1980s, but due to the absence of sincere cooperation and irregularities, these markets became unstable and unsecured to the global investors. The stock markets of this region became further vulnerable in the 1990s after the Asian Financial Crisis. This caused less attractive for the portfolio investment. The wide instability

\footnotetext{
* Md. Saifur Rahman, College of Business, RMIT University, Melbourne, Australia, Email: masaifur@yahoo.com

** Farihana Shahari, Department of Finance, Faculty of Economics and Management Science, International Islamic University, Malaysia, farihana_shahari@iium.edu.my
} 
in the stock market subsequently dried up the international reserves and reduced the value of national currencies vis-à-vis against US Dollar by more than 40 percent. The collapse in regional stock markets affected the nations and households' wealth and dented the banking system. Both local and foreign investors fled from this part of the continent due to lack of confidence and market instability. The implementation of new economic policies and adjustments by governments as part of the initiatives to tackle the crisis were painful lessons to both the governments and the people. As part of the initiatives to assist the catastrophic economic condition amongst the Southeast Asian economies, the ASEAN economies with three northeast economies, i.e., China, Japan and South Korea introduced a number of financial/monetary cooperative steps, notably known as Chiang-Mai Initiative (CMI), Asian bond market (ABM), and so forth. The rationale for establishing these initiatives are; to cooperate and support the regional countries and to ensure stability and attractiveness as an investment hub.

Essentially, when capital markets are liberalized, the members of regional economies become more integrated, thus their intra-financial and economic activities increase, Rahman et al., (2015). When financial markets integrate and work collectively, the markets develop at a higher speed compared to working independently. It will also be more attractive to investors. Integration of financial markets also creates avenues for members to gain fresh capital and expansion of liquidity in the financial markets and/or the banking system. The integration process will facilitate cross-border investors in issuing financial products. This subsequently increases the trading volume in regional markets. The markets become more liquid and the participants (the market players) may access the market with low transaction costs and low equity premium. Members of the more developed members are likely to share and provide technical support to their economic partners. It is crucial for the financial markets in the group to be efficient in mobilizing capital or savings. An efficient market is a prerequisite to a country that is involved in the integration process because these efficient markets could absorb substantial foreign funds and could withstand pressures on financial variables, i.e., interest rate and exchange rate. As markets get more advanced, efficient and liquid, households and firms will benefit (Pagano et al. 2001 and 2002). This will subsequently attract investors from the regional group and the international participants, as the markets are integrated and fundamentally strong.

The degree of ASEAN+3 capital market openness is reflected by the actual intra-regional financial transactions. Figure 1 indicates the intra-regional Foreign Direct Investment (FDI); denoting that The Asian intra-regional investment is in a 
relatively instable environment. None of the Asian regional bloc, including ASEAN+3 has presented a smooth intra-regional investment growth. Their investment growth in 2007, 2008 and 2009 is negative, positive and negative respectively. This is an indication of high volatility and inconsistency in the intraregional FDIs among ASEAN+3 economies.

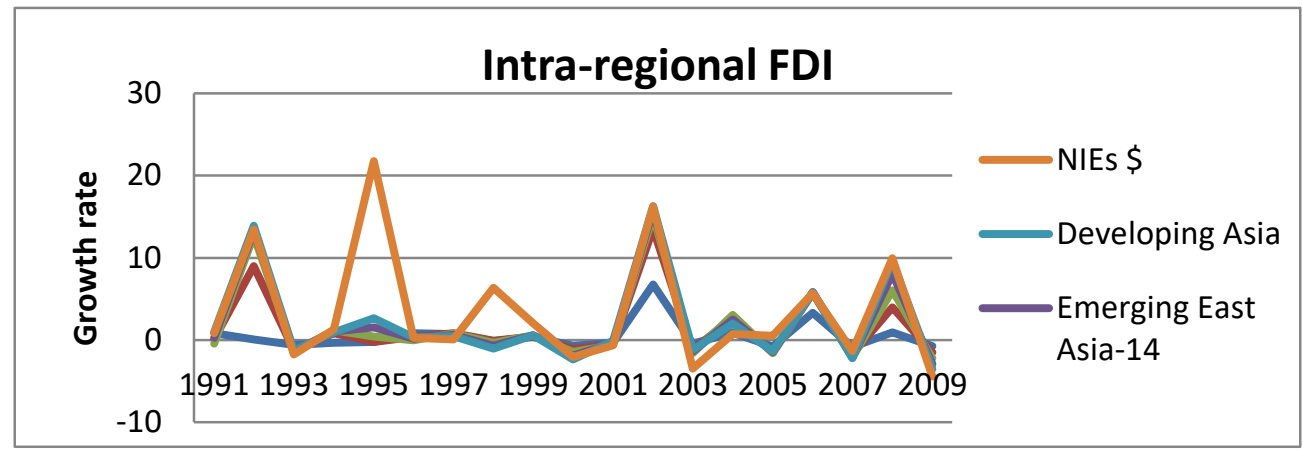

Figure 1. Intra Regional FDI share

Source: UNCTAD FDI database, Note: Foreign direct investment (FDI) share is the percentage of regional FDI inflows to total FDI from the investing region. A higher share indicates a stronger preference for the region and a higher degree of integration

Furthermore, the world trades in 2000, 2005, 2010 and 2011 are \$12891.47, $\$ 20969.86$, \$30210.12 and \$35977.62 million respectively. Conversely, the trades of ASEAN+3 in 2000, 2005, 2010 and 2011 are \$2461.16, \$4317.20, \$7330.19, and $\$ 8791.16$ million respectively. The figures indicate that one-fourth of the total world trade is from ASEAN+3 bloc. The trade growth of ASEAN+3 bloc is higher than that of the world; the growth of world's trade is about 19\% and ASEAN+3's trade growth is about $20 \%$ (statistics are available on request). These statistics indicate that APT countries contribute significantly in terms of trade towards world economy. It further explains that the intra-trades among Asian economies are very low due to its external trade relationship. Most of the APT member countries have FTAs with other countries as discussed earlier. Each of the countries maintains their trade-relationship wherever there are potentialities as individual member countries are involved in bilateral traderelation with external economies. For example, Singapore, Laos, Myanmar and Vietnam prioritize EU; Malaysia, Thailand and Cambodia prioritize US; and Indonesia, Philippines and Brunei prioritize Japanese market as their trading partners. If we take a glance at EU regionalism, we see the opposite trend of ASEAN bloc. The level of economic integration among EU economies is much higher than that of the ASEAN, where the intra-trades in EU bloc in 1950s and 2010s are about $50 \%$ and 
$60 \%$ respectively compared to the current $25 \%$ in ASEAN +3 today. The statistics of intra-investments and intra-trades along with the world trades indicate that the ASEAN+3 financial markets are not completely cooperative towards member economies and this may cause market vulnerabilities to the foreign investors. The member economies are not integrated, but are rather in cooperation with countries other than the APT region. This causes the regional economies to be less attractive to the foreign investors due to lack of market efficiency. Based on the statistics and the discussion above, this study will attempt to address the following questions:

a. Do the early capital market openness and ASEAN+3 financial cooperation agreement lead to cooperation among the member stock markets and draw the attention of foreign investors?

b. Do the ASEAN+3 economies achieve regional active cooperation, market efficiency and information transparency?

c. Do the capital market openness of one high income country respond to that of the other high income countries or to that of the low income countries as well?

d. Are the capital markets of ASEAN+3 economies stable and secured for the foreign investment?

This study contributes in several aspects; first, even though there are several studies in the area of stock market integration, they do not focus on the degree of capital market openness and investment potentialities in ASEAN+3 capital markets. Secondly, according to Guillaumin (2009) and Rahman et al., (2014 a,b), market openness may cause the low income economies to respond to other low income economies and high income to other high income economies. In this case, the regional markets are unable to attract the foreign investments. This study investigates whether the low income economies open their capital markets to the high income countries in order to attract the foreign investors, which has not been examined before in the case of ASEAN+3 economies. Thirdly, this study employs several advance econometrics techniques: Vector Autoregression (VAR)-based Vector Error Correction Methods (VECM), Impulse Response Function (IRF) and Toda Yamamoto (TY) in the investigation process in order to justify the robustness of the findings. And finally, this study provides empirical findings for the ASEAN+3 policy makers, which may create awareness on the status of regional economies and help potential investors to decide on whether or not to invest in ASEAN+3 regional economies.

There are ample studies that focus on the global capital market openness in different economies. For example, a group of studies (Thompson, 1994; Ewing et al, 1999; Aggarwal and Kyaw, 2005; Morelli, 2010) focus on capital market openness 
and investment opportunity in developed economies, while another group of studies (Carrieri et al, 2002; Bekaert and Harvey, 2003; Eizaguirre and Biscarri, 2006; Chambet and Gibson, 2008; Beiney and Candelon, 2011) concentrate on the capital market integration among emerging economies. This study predominantly reviews the literatures that focus on the Asian economies and financial market openness.

Janor and Ali (2007), Rim and Setaputra (2008), Chen et al (2009), Yu, et al (2010) investigated the stock market integration and found stock markets from the Asian region to be partially-integrated. Partial-integration facilitates the diversification opportunity for portfolio investment. Nevertheless, Ibrahim (2006) documented that stock markets of this region are fully segmented and it facilitates the foreign investors in diversifying their portfolio investment. The literatures on post financial crisis indicate that the Asian economies are more integrated due to contagion and market openness. Yu, et al, (2010) investigates the market integration by means of standardized trace statistic or Eigen value of cointegration test. Their findings show that the four dragon regions (Hong Kong, Taiwan, Singapore and South Korea) became highly integrated amongst them during the financial crisis. They further explained that the markets are highly integrated during the crisis periods because of volatility spill over and contagion effects. Asian emerging markets became integrated as well after the crisis, whilst the four dragon regions became segmented during the post-period as they initiated their own individualistic domestic policies that do not comply with other member countries. These findings are supported by Mukherjeea and Mishra (2010) and Oh et al (2010), who found the ASEAN economies as more cooperated due to stock market spill over effect.

Additionally, Majid, et al (2009) examines the influences of sub-prime crisis on the ASEAN region, considering stock indices from $15^{\text {th }}$ February to 31 December, 2008. The sub-prime crisis period is during post-APT agreement. During this period, the ASEAN region is weakly integrated with each other. The subprime crisis influences the stock markets of Malaysia and Indonesia. It further indicates that during the subprime crisis, the markets became more integrated due to contagion effect. Saini (2002) and Lim (2009) and investigate the integration process of stock markets in ASEAN-5 during the post-crisis using data from 1990 to 2008. They found that member economies are highly integrated. The crisis caused instability in some of countries such as Indonesia. The domestic economy was badly affected by the crisis and the stock markets fell sharply. These shocks to the domestic economy lead the member countries of the ASEAN region to be interdependent among themselves. Rim and Setaputra (2008) investigate the stock 
market integration in East Asian countries, US and Japan, employing GARCH. They used daily stock indices from 1992 to 2006, which have been subdivided into three periods; pre-crisis, during crisis and post-crisis. The findings indicate that the stock markets in East Asia are improving their integration process. During the crisis period, the markets were integrated due to contagion effects, which was supported by the significant variance term. Along with that, significant error and variance terms indicates that stock markets of these regions are facing spill over effects after the crisis period and therefore, the markets are more integrated during post-crisis period, which is also supported by Stehle (1977).

Moreover, Janor and Ali (2007) investigated on whether or not the stock markets became more integrated after the Asian financial crisis. They investigated further to determine whether financial liberalization contributes to the integration of the markets in this region. Singapore spearheaded by relaxing the financial constraints (tight rules of interest rates and exchange control) amongst member countries in the ASEAN region. This action is followed by Malaysia in liberalizing the capital markets (Phylaktis, 2002). They found contradicting results between bivariate and multivariate cointegration test. Normally, the findings of bivariate cointegration test can present maximum one cointegrating vector out of two I(1) series which causes misspecification of the result. Hence, they prefer multivariate test as it overcomes the problems of misspecification of the results. The multivariate test reveals that more than one market is integrated with each other after the crisis period. Singapore is the most influential market in this region and affects all the markets except the Philippines. The integration has increased during the post-crisis compared to precrisis. Moreover, in global integration, Japan is more influential in this region as compared to the U.S. market. The crisis has led to more integration among the regional blocs, ASEAN and globally but to re-affirm, the integration process is incomplete, which means there is still room for diversification benefits. The financial liberalization leads to integration but the reverse takes place when the capital control is imposed. The findings of Ibrahim (2006) indicate that Malaysian stock market is segmented after the capital control is imposed. Thus, the stock price movements on the Malaysian stock market (KLSE) did not respond accordingly to that of the other countries during this period.

The organization of this paper is as follows: data and variables are discussed in Section 2.0 followed by methodology in Section 3.0. The analysis of findings is discussed in Section 4.0, while concluding remarks along with policy recommendation are described in Section 5.0 


\section{DATA AND VARIABLES}

In order to examine the capital market cooperation for ASEAN+3, this study employs daily stock indices for the period of $31^{\text {st }}$ December 1992 to $4^{\text {th }}$ July 2012. The stock indices are collected during this period, as the capital market openness of this region is reflected in this period. The movement of the stock indices is presented in Figure 2:

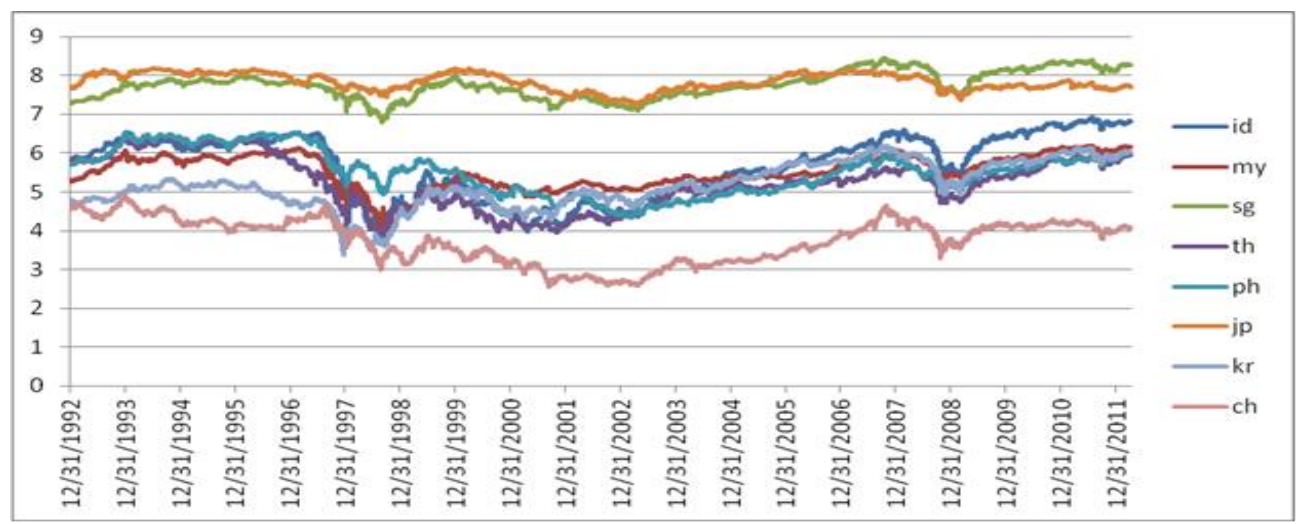

Figure 2. Stock Indices of ASEAN+3

Note: To draw the graph, all of the stock indices have been transformed into natural logarithm over $12 / 31 / 1992$ to $4 / 9 / 2012$ and ploted against time.

The stock indices are indexed by Morgan Stanley Capital International (MSCI) world index, which is collected using DATASTREAM. Total number of observation is 5028, which are collected on a daily basis and in a common currency i.e., US dollar and therefore, are transformed into natural log form in order to apply the investigation process. For the purpose of examining the comparatively enhanced investment opportunities in high or low income countries, this stock indices of ASEAN+3 have been disaggregated into two parts; high income economies (Japan, South Korea and Singapore) and low income economies (Malaysia, Indonesia, Thailand, Philippines and China). The classification of countries are based on Gross National Income (GNP) facilitated by World Bank (2010); countries are classified under high income if their per capita GNP is above US\$12,276 and low income if the per capita GNP is below US\$12,276. To verify the data series, the stock indices are tested for descriptive statistics and crosscorrelation as shown in Table 2: 
Table 2. Descriptive and Coefficients of Correlation

\begin{tabular}{|c|c|c|c|c|c|c|c|c|}
\hline & \multicolumn{3}{|c|}{ High income economies } & \multicolumn{5}{|c|}{ Low income economies } \\
\hline & JP & KR & SG & MY & PH & ID & $\mathrm{CH}$ & TH \\
\hline Mean & 7.837 & 5.166 & 7.758 & 5.520 & 5.523 & 5.676 & 3.752 & 5.238 \\
\hline Median & 7.818 & 5.119 & 7.757 & 5.480 & 5.568 & 5.885 & 3.916 & 5.244 \\
\hline $\begin{array}{l}\text { Maxi } \\
\text { mum }\end{array}$ & 8.192 & 6.197 & 8.448 & 6.198 & 6.548 & 6.922 & 4.922 & 6.480 \\
\hline $\begin{array}{l}\text { Minim } \\
\text { um }\end{array}$ & 7.234 & 3.369 & 6.796 & 3.993 & 4.335 & 3.752 & 2.554 & 3.783 \\
\hline Std. Dev. & 0.220 & 0.575 & 0.342 & 0.435 & 0.575 & 0.800 & 0.570 & 0.679 \\
\hline Skewness & -0.357 & -0.319 & 0.007 & -0.606 & 0.004 & -0.412 & -0.322 & -0.047 \\
\hline Kurtosis & 2.236 & 2.821 & 2.322 & 3.069 & 2.032 & 1.859 & 2.007 & 2.006 \\
\hline Jar-Bera & $\begin{array}{c}229.16 \\
2\end{array}$ & 91.799 & 96.204 & $\begin{array}{c}308.97 \\
8\end{array}$ & $\begin{array}{c}196.17 \\
9\end{array}$ & $\begin{array}{c}415.06 \\
2\end{array}$ & $\begin{array}{c}293.44 \\
6\end{array}$ & $\begin{array}{c}208.88 \\
6\end{array}$ \\
\hline Observn & $\begin{array}{c}5028.0 \\
0\end{array}$ & $\begin{array}{c}5028.0 \\
0\end{array}$ & $\begin{array}{c}5028.0 \\
0\end{array}$ & $\begin{array}{c}5028.0 \\
0\end{array}$ & $\begin{array}{c}5028.0 \\
0\end{array}$ & $\begin{array}{c}5028.0 \\
0\end{array}$ & $\begin{array}{c}5028.0 \\
0\end{array}$ & $\begin{array}{c}5028.0 \\
0\end{array}$ \\
\hline \multicolumn{9}{|c|}{ Cross - correlation } \\
\hline Indices & JP & KR & $\mathrm{SG}$ & MY & $\mathrm{PH}$ & ID & $\mathrm{CH}$ & TH \\
\hline $\mathrm{JP}$ & 1.000 & & & & & & & \\
\hline KR & 0.251 & 1.000 & & & & & & \\
\hline SG & 0.473 & 0.861 & 1.000 & & & & & \\
\hline MY & 0.449 & 0.717 & 0.823 & 1.000 & & & & \\
\hline $\mathrm{PH}$ & 0.653 & 0.171 & 0.497 & 0.650 & 1.000 & & & \\
\hline ID & 0.469 & 0.698 & 0.821 & 0.915 & 0.744 & 1.000 & & \\
\hline $\mathrm{CH}$ & 0.597 & 0.328 & 0.594 & 0.700 & 0.880 & 0.835 & 1.000 & \\
\hline $\mathrm{TH}$ & 0.579 & 0.499 & 0.606 & 0.830 & 0.829 & 0.884 & 0.820 & 1.000 \\
\hline
\end{tabular}

Note: Jar-Bera and $\mathrm{Ob}$ represent the normality test Jarque-Bera and Observation respectively. The stock indices of Japan, South Korea, Singapore, Malaysia, Philippines, Indonesia, China and Thailand are indicated by JP, KR, SG, MY. PH, ID, CH and TH respectively.

The average returns of stock markets in ASEAN+3 regional markets differ from one economy to another. The highest mean returns are noted by Japanese stock market, followed by Singapore. The least investment return is in the Chinese stock market. In general, the mean returns in high income economies are higher than that of low income economies, which indicates that the stock markets of high income economies are offering better returns. Furthermore, the cross-linkage of regional stock markets is indicated by the correlation of coefficients. The correlation of coefficients of Malaysia-Indonesian stock returns is the highest (91.5\%) followed by that of Indonesia-Thailand (88.4\%), Philippines-China $(88.0 \%)$, Singapore-Korea $(86.1 \%)$ and Indonesia- China $(83.5 \%)$. Though the returns are paid by high income economies, the investment returns among low 
income economies are more correlated. These findings clearly indicate that the stock markets of ASEAN+3 economies are not efficient as a whole, following the regional market shocks that increase the investment risk in this region.

Finally, the study undertakes the diagnostic and stability test to confirm whether or not the models employed in this study are correctly specified. Majority of the test of L-Jung Box and $\mathrm{LM}^{1}$ test for autocorrelation, Heteroskedasticity ${ }^{2}$ test for ARCH effect and Ramsey RESET ${ }^{3}$ test for stability shows that the models used to determine the investment opportunities are free from the problems of autocorrelation, ARCH effect and instability in the respective data series. The Jarque-Bera $^{4}$ normality test indicates that the error terms are not normally distributed but according to previous literatures, the models are acceptable even though normality test shows the non-normality.

\section{The econometric models}

Stationary test

$$
\begin{aligned}
& \Delta y=\delta_{0}+\eta y_{t-1}+\sum_{i=1}^{m} \beta_{i} \Delta y_{t-i+1}+u_{t} \\
& \Delta y=\delta_{0}+\xi t+\eta y_{t-1}+\sum_{i=1}^{m} \beta_{i} \Delta y_{t-i+1}+u_{t}
\end{aligned}
$$

Equation (1) and (2) are known as Augmented Dickey fuller (ADF) test that are used for stationarity in the data series. Equation (1) follows the random walk with drift while equation (2) follows the random walk as well but with both drift and deterministic time trend. Both of the equations follow the assumptions of homoscedasticity, meaning the variances of error terms $\left(\varepsilon_{\mathrm{t}}\right)$ are independent.

$$
\Delta y=\delta_{0}+\xi t+\eta y_{t-1}+u_{t}
$$

\footnotetext{
${ }^{1}$ The null hypothesis of LM test is, $\mathrm{H}_{0}$ : there is no autocorrelation in the residuals

2 The null hypothesis is, $\mathrm{H}_{0}$ : there is no heteroskedasticity problem in error terms. Therefore, rejection of null hypothesis indicates the presence of ARCH effect.

${ }^{3}$ The null hypothesis is, $\mathrm{H}_{0}$ : the error term is normally distributed. Ramsey (1969) came up with Regression Specification Error Test (RESET) test for model speficication purposes where rejection of null hypothesis indicates the non-normality in the error terms of stock data serises.

${ }^{4}$ The null hypothesis of Jarque- Bera test indicates, $\mathrm{H}_{0}=$ residuals are normally distributed. Therefore, the rejection of null hypothesis indicates the non-normality in the error terms.
} 
Equation (3) is known as Phillis-Perron (PP) and is used for stationary test. It allows correlation of heteroskedasticity in contrast to ADF. Therefore, the PP is a better approach when ADF fails for stationarity test due to heteroskedasticity. The series is said to be stationary under both of ADF and PP when the null hypothesis of the unit root problem or non-stationary is rejected. In order to perform the test, the lag length $(\mathrm{m})$ is selected based on the criteria of Akaike Information Criterion (AIC), $A I C=n \sum_{i=1}^{k} \hat{u_{t}^{2}}+2 k_{t}$, where, $u_{t}$ is the residuals and $\mathrm{k}$ is the number of parameters. The third approach of testing the stationarity is Kwiatkowski- PhillisSchmidt-shin (KPSS) through the following formula:

$$
\Delta y=\delta_{0}+\xi t+\eta \sum_{i=1}^{t} u_{t-1}+\varepsilon_{t}
$$

The data series is stationary under this mechanism when the null hypothesis of stationary is not rejected. It means the data series $\left(y_{t}\right)$ in null hypothesis is the trendy stationary around its deterministic trend while the alternative indicates nonstationary.

\section{Cointegration technique}

The cointegration test proposed by Johansen (1991) and Johansen and Juselius (JJ) (1990) is used for examining the investment opportunities among the markets via the following equation:

$$
\Delta y_{t}=\delta_{0}+\prod y_{t-k}+\Phi_{1} \Delta y_{t-1}+\Phi_{2} \Delta y_{t-2}+\ldots \ldots \ldots+\Phi_{k} \Delta y_{t-k}+\varepsilon_{t}
$$

Where, $y_{t}$ indicates an $\mathrm{n} x 1$ vector of variables, $\delta_{0}$ symbolizes vector of constant, $\prod$ is equal to $\alpha \beta^{\prime}$ in which $\alpha$ is an $n \times 1$ column vector that represents the speed of short-term adjustment of disequilibrium and $\beta^{\prime}$ is an $1 x n$ cointegrating row vector that represents the coefficient of long-run investment opportunity. $\Phi_{\mathrm{i}}$ is an $n x n$ matrix which represents the short-term, $\varepsilon_{\mathrm{t}}$ is a white noise error term and finally $\mathrm{k}$ is the order of Autoregression. The presence of long- 
run relationship is identified by the cointegrating vector which is found through equations (6) and (7):

$$
\begin{aligned}
& \lambda_{\text {trace }}(r)=-T \sum_{i=r+1}^{n} \ln \left(1-\hat{\lambda}_{t}\right) \\
& \lambda_{\max }(r, r+1)=-T \sum_{i=r+1}^{n} \ln \left(1-\hat{\lambda}_{t}+1\right)
\end{aligned}
$$

The rank (r) of long-run relationship in equation (6) is estimated by trace statistics (TS) referred by $\lambda_{\text {trace }}$ that indicates the maximum number of cointegrating vectors. The likelihood test statistics is considered for the hypothesis in order to justify the number of maximum cointegrating vector. The maximum eigenvalue in the equation (7) indicated by $\lambda_{\max }$ represent the test statistics for the hypothesis of rank (r) against cointegrating vector $r-1$. If the values of $\lambda_{\text {trace }}$ and $\lambda_{\max }$ are between $1<\mathrm{r}<\mathrm{n}$, it will indicate the presence of cointegrating vector, the VECM can be formed as follows:

$$
\Delta y_{t}=\delta_{0}+\psi E C T_{t-1}+\Phi_{1} \Delta y_{t-1}+\Phi_{2} \Delta y_{t-2}+\ldots . .+\Phi_{k} \Delta y_{t-k}+\varepsilon_{t}
$$

If the model represents no long-run opportunity $(r=0)$, then it is addressed in the following form:

$$
\Delta y_{t}=\delta_{0}+\Phi_{1} \Delta y_{t-1}+\Phi_{2} \Delta y_{t-2}+\ldots \ldots+\Phi_{k} \Delta y_{t-k}+\varepsilon_{t}
$$

The equation (9) represents the VAR model when the null hypothesis of no long-run relationship is not rejected or rank $(r)$ is zero. Vector Error Correction Method (VECM) cannot be used in this case; thus, VAR is used instead.

The findings of these econometric techniques indicate the degree of stock market cooperation that assists the domestic and foreign investors to decide whether or not to invest in ASEAN+3 capital markets. The markets become competitive, efficient and transparent when they are cooperative. The cost of capital to individuals/households and firms are reduced. Investors in the domestic economy as well as foreign countries or partners in the group will be offered a low cost of 
borrowing (Guiso, et al., 2004). Regardless of the size of the economies (or markets), each of the countries can access to the financial system of each other in term of accessing cheaper costs of capital or loans. Furthermore, the capital market openness promotes high standards of financial regulations such as accounting standards, corporate governance, prudential market surveillance, and banking supervision. Therefore, the regional capital market openness and market cooperation invites both domestic and foreign potential investors to invest in regional stock markets. When the markets are co-integrated in the short-run, the long-run investment opportunity arises as the markets are cooperated in long-run process.

\section{Analysis of findings}

\section{Unit-root test}

The investigation of long-run and short-run cooperation requires the identification of whether the series are stationary or non-stationary. If the series are non-stationary at the level forms or integrated at order one, we can proceed to investigate the stock market cooperation in the long-run. The findings of stationary tests through ADF, PP and KPSS are presented in Table 3:

Table 3. Unit Root Test result

\begin{tabular}{|l|c|c|c|c|c|c|}
\hline \multirow{2}{*}{ Var } & \multicolumn{2}{|c|}{ ADF } & \multicolumn{2}{c|}{ PP } & \multicolumn{2}{c|}{ KPSS } \\
\cline { 2 - 7 } & Level & $1^{\text {st }}$ diff & Level & $1^{\text {st }}$ diff & Level & $1^{\text {st }}$ diff \\
\hline $\mathrm{My}$ & -1.5340 & $-12.055^{*}$ & -1.4432 & $-63.956^{*}$ & $1.314^{*}$ & 0.1295 \\
\hline $\mathrm{Sg}$ & -2.1372 & $-15.423^{*}$ & -1.8700 & -65.532 & $1.0811^{*}$ & 0.0782 \\
\hline $\mathrm{Th}$ & -1.1967 & $-16.372^{*}$ & -0.9482 & $-61.303^{*}$ & $1.7265^{*}$ & 0.3013 \\
\hline $\mathrm{Id}$ & -1.4902 & $-10.585^{*}$ & -1.1270 & $-61.893^{*}$ & $1.7814^{*}$ & 0.2431 \\
\hline $\mathrm{Ph}$ & -1.0260 & $-17.421^{*}$ & -0.7960 & $-59.127^{*}$ & $1.7415^{*}$ & 0.2641 \\
\hline $\mathrm{Ch}$ & -1.5949 & $-18.1951^{*}$ & -1.5125 & $-62.936^{*}$ & $1.9102^{*}$ & 0.2784 \\
\hline $\mathrm{Jp}$ & -2.3534 & $-31.5068^{*}$ & -2.4335 & $-73.468^{*}$ & $0.5633^{*}$ & 0.0779 \\
\hline $\mathrm{kr}$ & -2.2887 & $-11.7347^{*}$ & -2.0604 & $-65.752^{*}$ & $0.9807^{*}$ & 0.0787 \\
\hline
\end{tabular}

Note: To test the unit root through Phillis-Perron (PP) and Kwiatkowski- Phillis-Schmidt-shin (KPSS), the bandwith is selected based on Newey-West Bandwidth. Phillis-Perron(PP) uses MacKinnon (1996) one-sided p-values. Test-statistics at the level are based on trend and intercept while at the first difference based on intercept. Lags length has been selected based on AIC. *, **,*** represent $1 \%, 5 \%$ and $10 \%$ significance level respectively.

In order to examine the presence of unit root problem, the stock indices are transformed into natural logarithm form. The unit root test is performed in two 
stages; at the level and first difference. The null hypotheses $\left(\mathrm{H}_{0}: \delta=0\right)$ of $\mathrm{ADF}$ and $\mathrm{PP}$ represents non-stationary data if null hypothesis is not rejected. The findings of ADF and PP indicate that the null hypothesizes of unit root problem at the level form are not rejected in any of the stock return services but at the first difference, all of the series are rejected at $1 \%$ level of significance, meaning that the stock return series are non-stationary at the level form but stationary at the first difference or I(1). The KPSS unit root technique works inverse to ADF and PP. The null hypothesis of KPSS is that, data series are trendy stationary or there is no unit root problem. The findings indicate that the null hypothesis of no unit root problem is rejected at $1 \%$ level of significance for all of the series, while at the first difference, the null hypothesis are not rejected which confirms that all of the stock return series of ASEAN+3 are integrated at order one or I(1).

\section{Cointegration test}

The unit root tests through ADF, PP and KPSS presented in Table 3 points out that all of the stock return series of ASEAN+3 are I(1), thus allowing us to proceed with the investigation of the long-run investment opportunity. The findings of $\lambda_{\text {trace }}$ and $\lambda_{\max }$ in Table 4 indicate that the null hypotheses of no long-run relationships are rejected in both of $\lambda_{\text {trace }}$ and $\lambda_{\max }$ at rank two, which means, at most two cointegrating vectors are identified in the system. The complete integrated markets requires $\mathrm{m}-1$ cointegrating vectors but the trace statistics presents only two cointegrating vectors, which means the ASEAN+3 stock markets provide a weak cooperation in the long-run. This may not attract virtuous investment opportunities for foreign investors in the ASEAN+3 stock markets.

Table 4. Johansen Cointegration test

\begin{tabular}{|c|c|c|c|c|}
\hline \multirow{2}{*}{$\begin{array}{c}\text { Rank } \\
(\mathrm{r})\end{array}$} & \multicolumn{4}{|c|}{ All of the economies of ASEAN+3 group } \\
\cline { 2 - 5 } & \multicolumn{3}{|c|}{$\lambda_{\text {trace }}$} & Lag length is 7 days \\
\cline { 2 - 5 } & Stat & CV (5\%) & Stat & CV (5\%) \\
\hline $\mathrm{r}=0$ & $199.519 * *$ & 159.5297 & $57.04278^{* *}$ & 52.36261 \\
\hline $\mathrm{r} \leq 1$ & $142.4762 * *$ & 125.6154 & $50.96853 * *$ & 46.23142 \\
\hline $\mathrm{r} \leq 2$ & 91.50772 & 95.75366 & 35.71146 & 40.07757 \\
\hline $\mathrm{r} \leq 3$ & 55.79625 & 69.81889 & 23.44455 & 33.87687 \\
\hline $\mathrm{r} \leq 4$ & 32.3517 & 47.85613 & 14.6663 & 27.58434 \\
\hline
\end{tabular}




\begin{tabular}{|c|c|c|c|c|}
\hline$r \leq 5$ & 17.6854 & 29.79707 & 11.2916 & 21.13162 \\
\hline$r \leq 6$ & 6.3938 & 15.49471 & 5.046616 & 14.2646 \\
\hline $\mathrm{r} \leq 7$ & 1.347184 & 3.841466 & 1.347184 & 3.841466 \\
\hline Rank & \multicolumn{4}{|c|}{ Low income economies } \\
\hline$(\mathrm{r})$ & \multicolumn{4}{|c|}{ Lag length is 7 days } \\
\hline $\mathrm{r}=0$ & $73.29835 * *$ & 69.81889 & 26.52106 & 33.87687 \\
\hline $\mathrm{r} \leq 1$ & 46.77729 & 47.85613 & 25.83022 & 27.58434 \\
\hline $\mathrm{r} \leq 2$ & 20.94706 & 29.79707 & 11.6346 & 21.13162 \\
\hline $\mathrm{r} \leq 3$ & 9.312461 & 15.49471 & 6.31982 & 14.2646 \\
\hline $\mathrm{r} \leq 4$ & 2.992641 & 3.841466 & 2.992641 & 3.841466 \\
\hline Rank & \multicolumn{4}{|c|}{ High income economies } \\
\hline$(\mathrm{r})$ & \multicolumn{4}{|c|}{ Lag length is 6 days } \\
\hline $\mathrm{r}=0$ & 27.82836 & 29.79707 & 19.35994 & 21.13162 \\
\hline $\mathrm{r} \leq 1$ & 8.468416 & 15.49471 & 8.144982 & 14.2646 \\
\hline $\mathrm{r} \leq 2$ & 0.323434 & 3.841466 & 0.323434 & 3.841466 \\
\hline
\end{tabular}

Note: The lag number is selected based on AIC. ** indicates the rejection of null hypothesis at $5 \%$ significance level. Null hypothesis will be rejected if trace or max-Eigen statistics exceed its critical value at the $1 \%$ or $5 \%$ significance level.

To add to the robustness of this study, the stock markets of low income and high income countries are investigated separately to justify whether they offer long-run investment opportunity distinctly. The result of $\lambda_{\text {trace }}$ indicates one cointegrating vector, while the $\lambda_{\max }$ does not provide any evidence of long-run cooperation. According to Alexander (2001), the indicators of $\lambda_{\text {trace }}$ are used in order to justify the long-run relationship in the case of different cointegrating vectors We conclude that one cointegrating vector exist among low income economies, whilst none of Trace and Max-Eigen value provides evidence of longrun relationship amongst high income economies.

Therefore, the findings indicate that low income economies offer insignificant long-run investment opportunity in ASEAN+3 stock markets. Similarly, the high income economies too do not provide any long-run support for foreign investment. The capital markets of high income economies are strictly tightened by their domestic regulation in the case of capital outflow and inflow. Even though the financial cooperation agreement of ASEAN+3 emphasizes on capital market openness and open for regional investment opportunities, in reality, the stock markets do not welcome foreign investment in long-run. Their 
markets are not cooperative in long-run, as focus is more on their individual stock markets (Lim 2009).

\section{Granger causality test result based on VECM}

The existence of cointegrating vector in $\mathrm{JJ}$ model allows us to investigate the coefficient of long-run error correction term (ECT), which indicates the speed of adjusting the long-run equilibrium.

Table 5 presents the short-run investment opportunity along with ECTs.

Table 5. Granger causality test result based on VECM

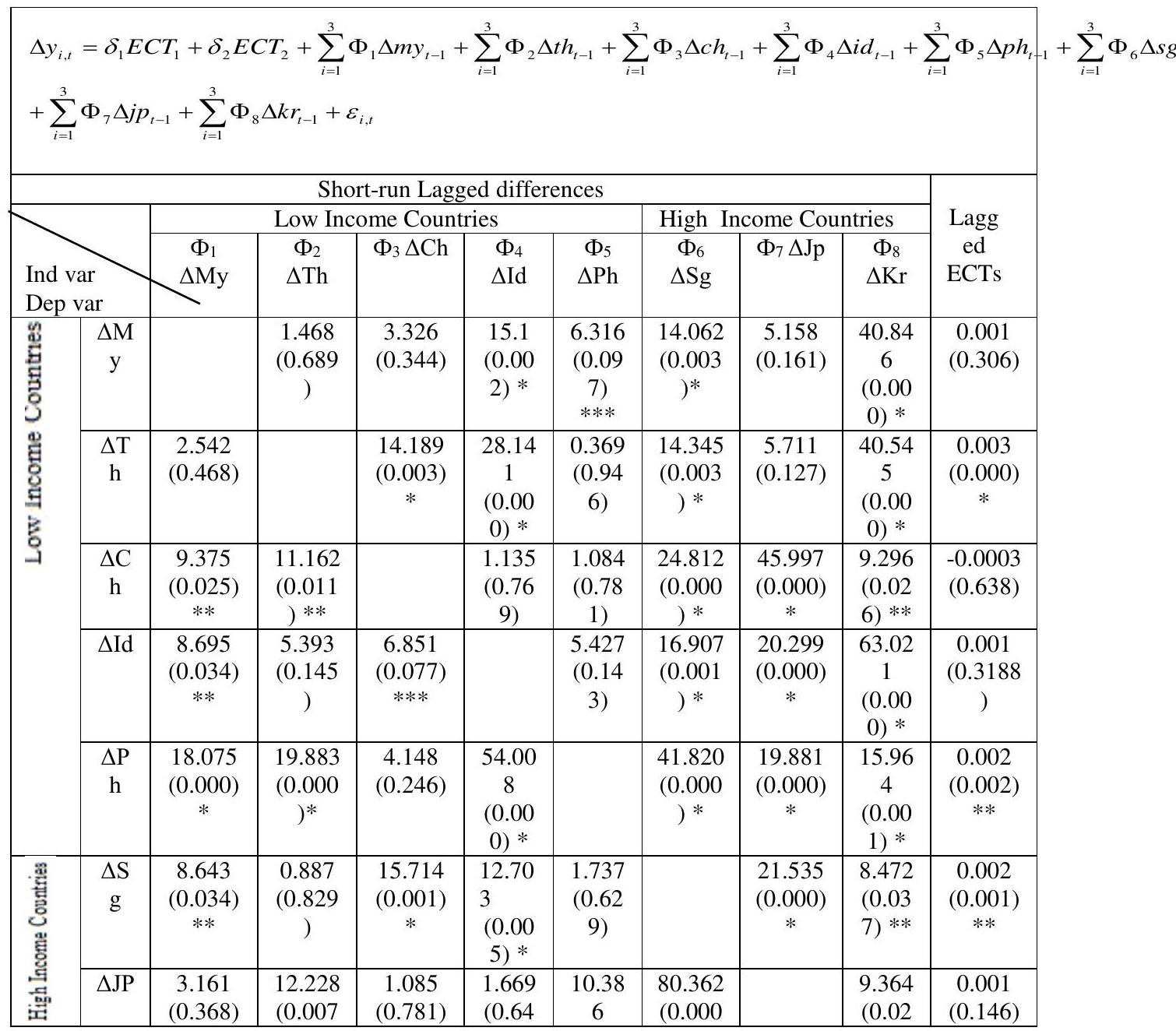




\begin{tabular}{|c|c|c|c|c|c|c|c|c|c|c|}
\hline & & )$^{*}$ & & $4)$ & $(0.01$ & )$^{*}$ & & $5)^{* *}$ & \\
\cline { 2 - 10 } & $\Delta \mathrm{K}$ & 11.062 & 33.375 & 10.916 & 2.810 & 3.818 & 63.761 & 8.305 & & 0.005 \\
& $\mathrm{R}$ & $(0.009)$ & $(0.000$ & $(0.012)$ & $(0.42$ & $(0.28$ & $(0.000$ & $(0.040)$ & & $(0.000)$ \\
& $*$ & )$^{*}$ & $* *$ & $2)$ & $2)$ & )$^{*}$ & $* *$ & & $*$ \\
\hline
\end{tabular}

Note: The result has been presented through WALD test which is based on chi-square while ECT is based on t-statistics. Lag length of VECM is 3 which is selected based on minimum AIC. Asterisks *, **, and $* * *$ represent $1 \%, 5 \%$ and $10 \%$ significance level.

The short-run granger causality in Table 5 focuses on the group magnitude of capital market cooperation and indicates the degree of cooperation between the two groups of stock markets. The rejection of null hypothesis against alternative hypothesis indicates that there is granger causality between the stock indices. The findings of Wald test indicate the two-way capital market cooperation between Singapore and Japan, Singapore and Korea, Japan and Korea, and so forth where most of the markets influence at $1 \%$ level of significance. This is supported by Oh et al. (2010). The lists of the stock markets that have bidirectional cooperative relationship are presented in Table 6 in the first column. The results indicate that all of the high economies are completely cooperative amongst themselves and offers cooperation to low income economies as well, e.g. Singapore-Malaysia, Korea-China, JapanPhilippines, etc. South Korea is the most cooperative capital market amongst all of the stock markets since it influences all of the stock markets at $1 \%$ significance level except at 5\% for Singapore. The stock markets of lower income countries are less cooperative compared to that of high income countries in the feedback relationship.

Table 6. Summary of VECM based-Granger causality direction

\begin{tabular}{|c|c|c|c|}
\hline $\begin{array}{c}\text { Mutual investment } \\
\text { opportunity }\end{array}$ & One & vay influences & No market cooperation \\
\hline 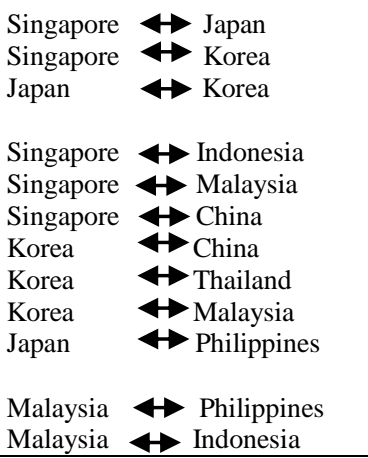 & $\begin{array}{l}\text { Japan } \\
\text { Japan } \\
\text { Singapore } \\
\text { Singapore } \\
\text { Korea } \\
\text { Korea } \\
\text { Thailand } \\
\text { Malaysia } \\
\text { Thailand } \\
\text { Indonesia } \\
\text { Indonesia } \\
\text { China }\end{array}$ & 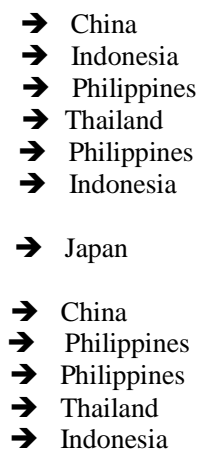 & $\begin{array}{l}\text { Malaysia }=\text { Philippines } \\
\text { Malaysia } \\
\text { Malaysia } \\
\text { Philippines } \\
\text { Japan } \\
\text { China }\end{array}$ \\
\hline
\end{tabular}




\begin{tabular}{|l|l|l|}
\hline $\begin{array}{c}\text { Mutual investment } \\
\text { opportunity }\end{array}$ & One way influences & No market cooperation \\
\hline Thailand $\leftrightarrow$ China & & \\
\hline
\end{tabular}

Note: $-\rightarrow$ and $\leftrightarrow$ lack of stock market cooperation, one way cooperation and two ways cooperation respectively

In addition, all of the high income economies influence majority of the low income economies in unidirectional way at $1 \%$ and $5 \%$ level of significance, e.g. Japan influences Indonesia, Singapore to Thailand, Korea to Philippines, etc. which comply with the findings of Gee et al. (2010). On the other hand, Thailand, from the lower income economies influences Japan. Some of the stock markets of low income economies cooperate with that of other low income economies, e.g. the stock market of Malaysia cooperates with Chinese stock market at $1 \%$ significance level in one way and Thailand and Indonesia cooperate with Philippines in another way. Finally, few economies do not have any comovement among their capital markets, e.g. Malaysia- Philippines, China-Philippines, etc. The overall findings indicate that: 1) all of the stock markets respond in the short-run to the capital market liberalization and could attract foreign investors, 2) The stock markets of high income countries are more influential compared to that of low income countries, which indicates that high income countries offer better investment opportunities in the short-run, 3) few of the stock markets present the lack of market cooperation which attracts the risk-taking investors to diversify their investment, and finally, 4) the positive and non-significant coefficients of ECTs $^{5}$ do not provide any evidence of long-run adjustments, which means the regional economies are offering short-run investment opportunities but do not respond to the long-run adjustments.

\section{Analysis of Impulse Response function}

Impulse response function represents the impact of shocks from independent variables on the dependent variables. Figure 2 indicates that stock returns of ASEAN+3 economies are affected mostly by their own

\footnotetext{
5 This study found two Error correction Term (ECTs). Following Arize (1995), this study uses the unique ECT based on largest Eigen-value.
} 
shocks and the member economies. The stock returns of China and Philippines immediately respond to their own shocks as well as member economies. Similarly, Thailand and Malaysia's shocks highly influence the stock returns of Indonesia. The stock price of Japan responds to the shocks of Philippines and Thailand in five days, meaning the stock prices of Japan takes longer time in responding to the shocks of Philippines and Thailand compared to other countries which takes a day or two. The shocks in Singapore influence the stock prices of Malaysia, Indonesia, Thailand and Philippines, whilst the stock prices of Singapore are mostly affected by the shocks of Indonesia and China.

Additionally, the stock prices of Indonesia and China decrease for 2 days and stabilize thereafter due to the shocks of Japan. The shocks in Malaysia lead to a reduction in the stock prices of South Korea. The speed of adjustment in the stock prices is quite fast according to IRF results. Most of the countries' stock prices increase in two or three days and stabilize thereafter. The findings of IRFs indicate that the majority of the stock markets of ASEAN+3 are responsive to the shocks of regional economies. The findings of IRFs are supported by that of VECM and further indicates that the stock markets of regional economies are partially cooperative and thus creates investment opportunities for the foreign investors especially in short-run. 

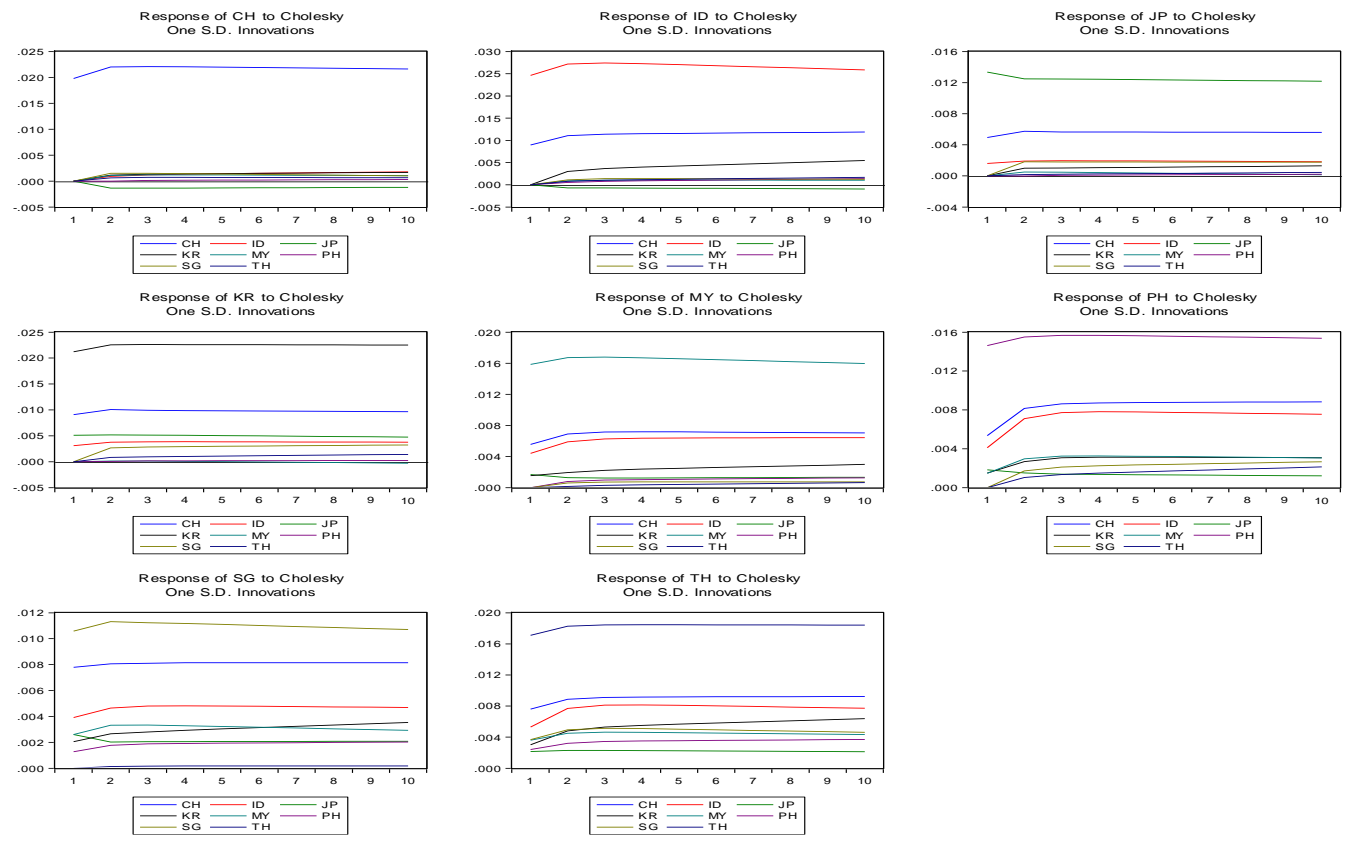

Figure 3. Impulse Response Function

Note: Impulse response is presented through cholesky with one S.D innovations while Degree of freedom is adjusted.

\section{CONCLUDING REMARKS}

This study examines the stock market cooperation amongst ASEAN+3 economies after the capital market openness and its impact on the investment opportunities in the regional economies. The VAR-based VECM, IRFs techniques have been employed in the investigation process. The findings indicate several outcomes: 1) the capital market openness in ASEAN+3 region leads to cooperation in the regional stock markets, 2) the stock markets of high income economies are more influential in changing the prices of stock markets of low income economies, 3) The stock markets are more volatile due to the prices changes and shocks in the economies of member countries in short-run, 4) the stock markets are partially cooperative in the long-run, and finally, 5) the regional markets adjust prices of stock returns due to the shocks in the regional economies without delaying much time.

These findings have implication towards potential investors of ASEAN+3 stock markets. Both risk-averse and risk-taking investors participate in the regional stock markets. The stock markets are significantly cooperative in the short-run 
especially in the high income economies and some of the low income economies in which stock markets are efficient in responding to the market information, market shocks and market transparency. The stock markets are ready to diversify the country-specific risk as they are cooperative due to capital market openness. Therefore, the risk-averse investors can enjoy the stock returns without much concern especially in the short-run as the cooperative markets reduce the investment risks of investors. Conversely, the risk taking investors can maximize their investment returns by diversifying their portfolio investment amongst those non-integrated economies. The risk-taking investors can appreciate the higher returns in ASEAN+3 stock markets as a compensation of higher market risk, especially in the low income economies.

This study suggests the policy makers of ASEAN+3 economies to be watchful on the regional stock markets. The capital markets have been mainly open in this region since the late 1980s, which was further enhanced after the financial cooperation agreement of ASEAN+3 in 1999. But unexpectedly, majority of the stock markets are not cooperative in long-run and amongst low income economies, and therefore the risk-averse investors have to be more mindful in investing in low income countries in the long-run. This study suggest the policy makers to focus on risk-averse investors rather than risk-taking investors, because the rick-averse investors require the regional stock markets to be tightly integrated, thus improving the efficiency, standards and transparency amongst the regional markets. This mechanism benefits both parties: the foreign investors to gain returns at a lower level of risk, while regional economies can improve their individual stock markets.

Finally, the policy makers can resolve the problem of non-integrity through the following mechanisms: first, the cooperation on intra-regional transactions is very low which has to be improved in order to increase the integrity in regional stock markets. If the market forces do not work, the policy makers have to impose the policy-enforcement to develop the intra-regional transactions such as intrainvestment, intra-trades, etc. Secondly, each of the member economies has to sacrifice the individual interest for the sake of regional market development and need to arrive at a platform for a common interest of cooperation of the regional capital markets and not for individual political mileage. Finally, the high income economies have to come forward in order to develop the regional stock market cooperation and draw the attention of foreign investors towards ASEAN+3 economies. 


\section{REFERENCES}

1. Aggarwal, R. and.Kyaw, N. A. 2005. "Equity market integration in the NAFTA region: Evidence from unit root and cointegration tests." International Review of Financial Analysis 14(4): 393-406.

2. Alexander, C. 2001. Market Models: a Guide to Financial Data Analysis. John Wiley and Sons: New York.

3. Arize, A. 1995. "The effects of exchange rate volatility on US exports: an empirical investigation." Southern Economic Journal 62(1): 34-43.

4. Beiney, M. and Candelon, B. 2011. "Liberalization and stock market co-movement between emerging economies." Quantitative Finance 11(2): 299-312.

5. Bekaert, G. and Harvey, C.R. 2003. "Research in emerging market finance: looking to the future." Emerging Markets Review 3(4): 429-448.

6. Bekaert, G., Harvey, C.R. and Lundblad, C. 2005. "Does financial liberalization spur growth?" Journal of Financial Economics 77(1): 3-55.

7. Carrieri, F., Errunza, V. and Hogan, K. 2002. "Characterizing world market integration through time", Working paper, McGill University

8. Chambet, A. and Gibson, R. 2008. "Financial integration, economic instability and trade structure in emerging markets." Journal of International Money and Finance 27(4): 654-675.

9. Chen, G., Firth, M., and Rui, O. 2002. "Stock market linkages: Evidence from Latin America." Journal of Banking \& Finance 26(6): 1113-1141.

10. Eizaguirre, J.C., and Gomes-Biscarri, J. 2006. "Changes in emerging market volatility and outliers: revisiting the effects of financial liberalization." Paper presented at the EEA-ESEM meetings, Vienna.

11. Ewing, B. T., Payne, J. E. and Sowell, C. 1999. "NAFTA and North American stock market linkages: An Empirical case." North American Journal of Economics and Finance 10(2): 443-451.

12. Gee, C. S., and Karim, M. Z. A. 2010. "Volatility spillovers of the major stock markets in ASEAN-5 with the U.S and Japanese stock markets." International Research Journal of Finance and Economics 44(2010): 156-168.

13. Guidi. F.and Gupta, R. 2013. "Market efficiency in the ASEAN region: evidence from multivariate and cointegration tests." Applied Financial Economics 23(4): 265-274.

14. Guillaumin, C. 2009. "Financial integration in East Asia: Evidence from panel unit root and panel cointegration tests." Journal of Asian Economics 20(3): 314-326. 
15. Guiso, L., Jappelli, T., Padula, M., Pagano, M. 2004a. "Financial market integration and economic growth in the EU." CEPR Discussion Paper, No 4395.

16. Guiso, L., Sapienza, P., Zingales, L. 2004b. "Does local financial development matter?" Quarterly Journal of Economics 119(3): 929-969.

17. Ibrahim, M. H. 2006. "Financial Integration and International Portfolio Diversification: US, Japan and ASEAN Equity Markets.” Journal of Asia-Pacific Business 7(1): 5-23.

18. Ibrahim, M. H. 2006. "Integration or Segmentation of Malaysia Equity Market: An Analysis of Pre- and Post-Capital Controls." Journal of the Asia Pacific Economy 11(4): 424-443.

19. Janor, H. and Ali, R. 2007. "Financial Integration of the Asean-5 Markets: Financial Crisis Effects Based On Bivariate and Multivariate Cointegration Approach." Investment Management and Financial Innovations, 4(4): 144-158.

20. Johansen, S. 1991. "Estimation and hypothesis testing of cointegration vectors in Gaussian vector autoregressive models.” Econometrica 59(6): 1551-1580.

21. Johansen, S., and Juselius, K. 1990. "Maximum likelihood estimation and interference on cointegration with application to the demand for money." Oxford Bulletin of Economics and Statistics 52(2): 169-210.

22. Lim, L. K. 2009. "Convergence and interdependence between ASEAN-5 stock markets." Mathematics and Computers in Simulation 79(9): 2957-2966

23. Lutkepohl, H. 1993. Introduction to Multiple Time Series. Second ed. SpringerVerlag: Berlin.

24. Majid, S. A., Meera, A. K., Omar, M. A., and Aziz, H. A., 2009. "Dynamic linkages among ASEAN-5 emerging stock markets." International Journal of Emerging Markets 4(2): 160-184.

25. Morelli, D. 2010 "European capital market integration: An empirical study based on a European asset pricing model." International Financial Markets Institution and Money 20(4): 363-375.

26. Mukherjeea, K. and Mishra, R. K. 2010. "Stock market integration and volatility spillover: India and its major Asian counterparts." Research in International Business and Finance 24(2): 235-251.

27. ${ }^{a}$ Md. Saifur Rahan, Mohamed Aslam and Wee-Yeap Lau (2014), The cross-linkage and comovement among ASEAN+3 exchange markets: An EGARCH-in-mean approach, Asian profile, Vol. 42(5), 445-464

28. ${ }^{b}$ Md. Saifur Rahman, Mohamed Aslam and Wee-Yeap Lau (2014), Financial Market Interdependency among ASEAN+3 Economies: Markov Switching Approach, The Empirical Economics Letters, 13(3):261-270. 
29. Md. Saifur Rahman, Mohamed Aslam, Wee-Yeap Lau and Farihana Shahari (2015), Does Financial Cooperation Agreement Influence the Real Economy?: A GMM Panel Data Approach on ASEAN+3 Countries, DLSU Business \& Economics Review, Volume 24 (2), pp.67-78

30. Oh, S. L., Lau, E., Puah, C. H., and Mansor, S. A. 2010. "Volatility co-movement of asean-5 equity markets.” Journal of Advanced Studies in Finance I(1): 23-30.

31. Phylaktis, K., and Ravazzolo, F. 2002. "Stock market linkages in emerging markets: implications for international portfolio diversification.” Journal of International Financial Markets, Institutions and Money 15(2): 91-106.

32. Pittis, N. 1999. "Efficient Estimation of Cointegrating Vectors and Testing for Causality in Vector Autoregressions.” Journal of Economic Surveys 13(1): 1-35.

33. Ramsey, J. B. 1969. "Test for Specification error in Classical Linear Least Squares Regression Analysis.” Journal of the Royal Statistical Society 31(2): 350-371

34. Rim, H. and Setaputra, R. 2008. "Studies on the Financial Market Integration and Financial, Efficiency: Evidences from Asian Markets.” The Business Review 10(2).

35. Ryan, K.F. and Giles D.E.A. 1998. "Testing for Unit Roots in Economic Time-Series With Missing Observations, Advances in Econometrics." 13: 203-242.

36. Saini, A. 2002. "Financial integration and the ASEAN-5 equity markets." Applied Economics 34(18): 2283-2288.

37. Stehle, R. E. 1977. "An Empirical Test of the Alternative Hypotheses of National and International Pricing of Risky Assets.” Journal of Finance 32(2): 493-502.

38. Thompson, A. 1994. "Trade liberalization, competitive advantage, and scale economies: Stock market evidence From Canada." Journal of International Economics 37(1): 1-27.

39. Toda,H.Y., and Yamamoto,T. 1995. "Statistical inference investor Autoregression with possibly integrated process." Journal of Econometrics 66: 225-250.

40. Yu,I.W., Fung, K. P., and Tam, C. S. 2010. "Assessing financial market integration in Asian Equity markets.” Journal of Banking and Finance 34(12): 2874-2885. 